\title{
Deformation Behaviour of Erodible Soil Stabilized with Cement and Quarry Dust
}

\author{
Arinze Emmanuel Emeka ${ }^{a}$, Agunwamba Jonah Chukwuemeka ${ }^{b}$, \\ Mama Benjamin.Okwudili ${ }^{\mathrm{b}}$ \\ ${ }^{a}$ Department of Civil Engineering, Michael Okpara University of Agriculture, Umudike, Nigeria \\ ${ }^{b}$ Department of Civil Engineering, University of Nigeria, Nsukka, Enugu State, Nigeria
}

\begin{abstract}
This study was carried using finite element software (Plaxis) in studying the Engineering behavior of erodible soil-quarry dust composite at a proportion of $50 \%$ quarry dust and $10 \%$ cement. It discusses the effects of decorative street light through numerical analysis using the Finite Elements Method. Plaxis program v8.2 was applied to model the soil behavior. The Mohr-Coulomb model reveals that the deformations are concentrated exclusively on the base course, with the appearance of plastic tension cut-off points on base course. The structure was subjected to double point loads of $50 \mathrm{kN} / \mathrm{m}$ each which resulted to $100 \mathrm{kN} / \mathrm{m}$. The results shows that the pavement deformed at load $85.16 \mathrm{kN} / \mathrm{m}$ which showed that the soil strength cannot withhold the pressure from the street light. The load displacement acting on the base of the highway in study is $2.47 \times 10^{-6} \mathrm{~m}$. The result also shows that failure was concentrated at the base course of the pavement. This was due to the presence of underground water beneath the phreatic level. The quarry dust is a good replacement to weak soil or a good additive to help improved a problematic soil. From analysis, the soil strength lies below the effective stress acting on the pavement which is equal to $85.16 \mathrm{kN} / \mathrm{m}$. It is advisable to replace some quantities of the existing soil and be replaced by quarry dust since quarry dust is a waste product from crushing of stones. Lastly, about $30 \%$ of the existing soil should be replaced by either the mixture of lateritic soil and quarry dust or the soil there should be used as subbase which may not be economical.
\end{abstract}

\section{Keywords:}

Erodible Soil; Quarry Dust; Soil Improvement; FEM Analysis.

\section{Article History:}

Received: 14 September 2018

Accepted: 31 October 2018

\section{1- Introduction}

There are numerous silty soil deposit in South-Eastern Nigeria susceptible to erosion [1-7]. In Oruruala-Ogudasa express, Isikwuato, Abia State, South-Eastern Nigeria, highly erodible and dispersive soils have been reported as a major problem resulting to failure of road shoulder and pavement as well as road embankment and canal banks [8-9]. The erodible soil in this terrain lies on erodible soil. Adopting a suitable soil improvement technique to control erosion is important to avoid structural damage and environmental degradation. Chemical stabilization has proven to be adequate and cost effective method of mitigating erosion or internal piping [10-15]. Moreover, traditional binders such as cement and lime have been a source of serious environmental problem ranging from negative impact on agriculture to changing the PH of soil and ground water. In addition soil stabilized with lime and/or cement tend to exhibit undesirable brittleness that affect stability of structure especially during cyclic and impact loading conditions [16-20]. In this research, quarry dust is used in combination with cement to reduce the cost and brittleness.

Secondly, the massive mining of sand for construction leads to change in ecosystem thereby triggering global warming. Quarry dust, being an industrial waste from quarry mines, is good replacement for sand in road construction [21, 22]. Chetia et al. (2017) and Chetia and Asuri (2016) utilized quarry dust in ground improvement [23, 24].

\footnotetext{
* CONTACT: Emmanuel.arinze@ mouau.edu.ng

DOI: http://dx.doi.org/10.28991/esj-2018-01157

(C) This is an open access article under the CC-BY license (https://creativecommons.org/licenses/by/4.0/).
} 


\section{2- Numerical Modelling}

The finite element method was used to analyze the flexible pavement section resting on an erodible soil along ORURUALA-OGUDUASA express. Plaxis v8.2 software is a two-dimensional Finite Element Method computer program that is used for stability analysis and deformation of soils in different geotechnical problems. In this method, analyzed structure is divided to smaller elements and displacements of any point in these elements are related to nodal displacements. The pavement section was considered as a 2-D plain strain problem and 15-noded structural solid element with medium refinements was used for the analysis. This software was used in comparing the effects of load on a horizontal plane and on a sloped plane.

Mohr-coulomb model are used for the simulation of soil behavior. The structure was subjected to the loads from double street light of load of $50 \mathrm{KN} / \mathrm{m}$. To model the surface load of the decorativestreet light and casted concrete wall, the total load is transferred to the pavement surface through an average contact pressure of $50 \mathrm{KN} / \mathrm{m}$.

This work was carried using 50\% quarry dust and $10 \%$ cement mixed with soil. The base of the structure was used as soil-quarry dust, while clay material was used for the subbase and subgrade modelled with Mohr-Coulomb criterion.

Table 1. Plaxis parameters

\begin{tabular}{cccc}
\hline Material & Values & Symbols & Units \\
Model & Mohr-Coulomb & - & - \\
Young Modulus & 240.63 & $\mathrm{E}$ & $\mathrm{Kpa}$ \\
Poisson's Ratio & 0.30 & $\mathrm{~V}$ & - \\
Wet Density & 2.18 & $\gamma_{\text {sat }}$ & $\mathrm{KN} / \mathrm{m}^{3}$ \\
Dry Density & 2.03 & $\gamma_{\text {unsat }}$ & $\mathrm{KN} / \mathrm{m}^{3}$ \\
Cohesion & 25.00 & $\mathrm{C}$ & $\mathrm{KN} / \mathrm{m}^{2}$ \\
Frictional Angle & 11.60 & $\emptyset$ & 0 \\
Angle of Dilantancy & 0 & $\varphi$ & 0 \\
Permeability $(\mathbf{x})$ & 1.00 & $\mathrm{k}_{\mathrm{x}}$ & $\mathrm{m} / \mathrm{day}$ \\
Permeability $(\mathbf{y})$ & 1.00 & $\mathrm{k}_{\mathrm{y}}$ & $\mathrm{m} / \mathrm{day}$ \\
\hline
\end{tabular}

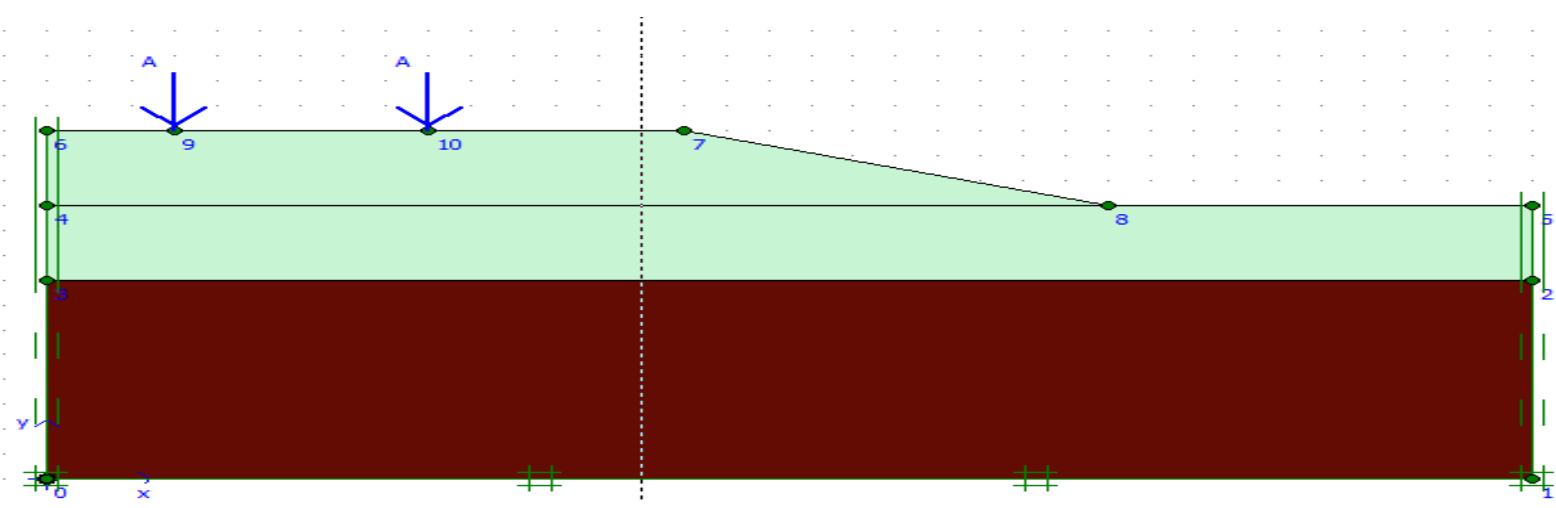

Figure 1. Pavement in study, Pavement bearing loads of $100 \mathrm{KN} / \mathrm{m}$.

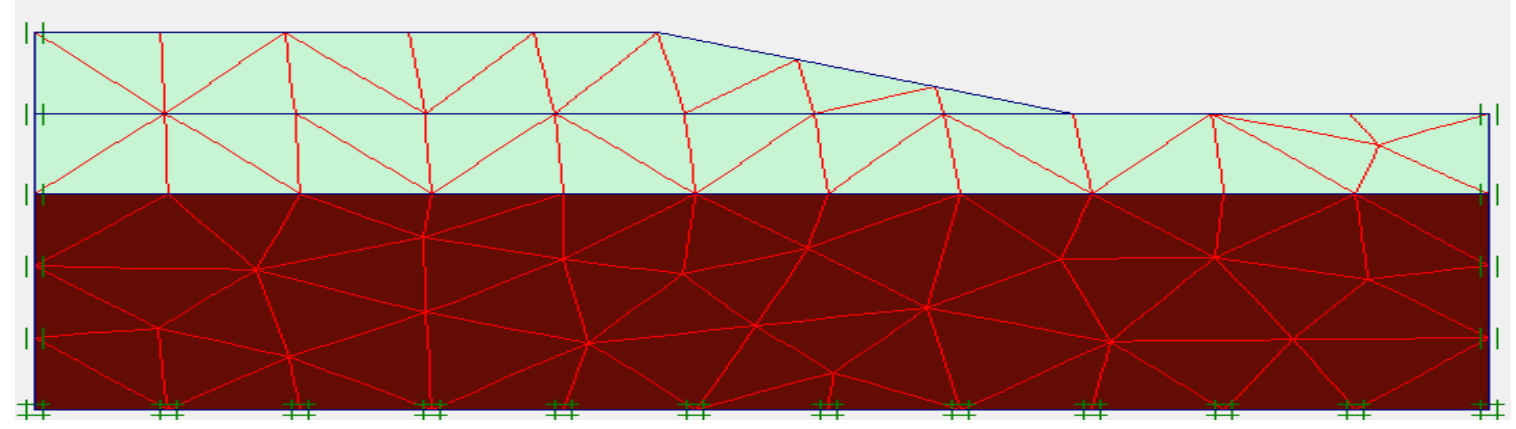

Figure 2. Generated Mesh, Generated Mesh of the pavement. 


\section{3- Results and Discussion}

\section{3-1- Deformation Behaviours by the Finite Elements Simulation}

Figure 3 shows the deformed mesh and settlement behavior of the Finite Elements models of erodible soil studied. The figure shows the effects of double decorative streetlight pole and casted concrete acting on the base of the ISUIKWUATO-UGUDUASA highway. The extreme load displacement acting on the base of the highway in study is $2.47 \times 10^{6} \mathrm{~m}$. Figure 3 also shows that the effect of the double decorative street light place which is equal to $50 \mathrm{KN} / \mathrm{m}$ caused great deformation at the point of application. This is caused by the nature of subgrade soil which is completely clayey material with higher pore water pressure. Figure 4 shows that the total displacement which act on the surface of the base. Its value is $2.47 \times 10^{6} \mathrm{~m}$. It show the accumulated displacements which come from both horizontal and vertical displacement. Failure was statically on the base of the pavement; failure occurred only on the base of the pavement. This failure is due to settlement of the soil. It was also due to the presence of water beneath the base of the pavement.

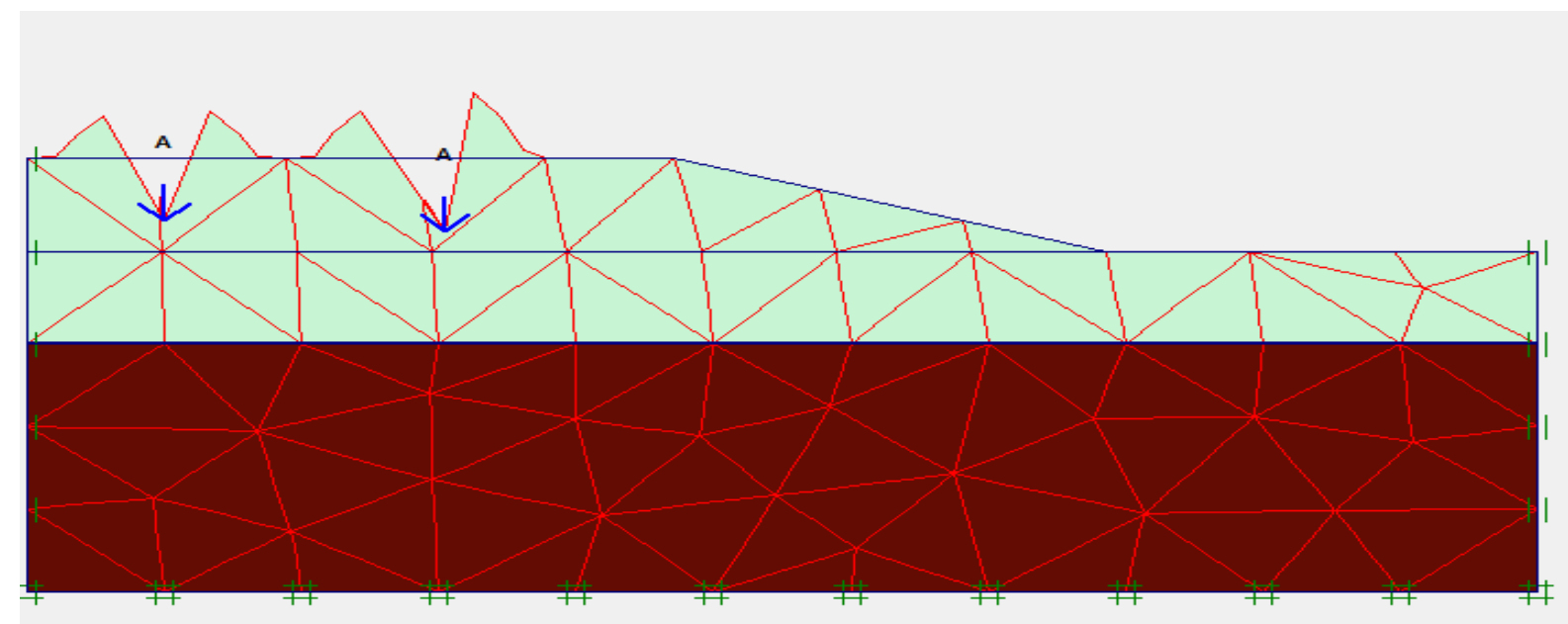

Figure 3. Deformed Mesh, Total displacement on the base $2.47 \times 10^{6} \mathrm{~m}$

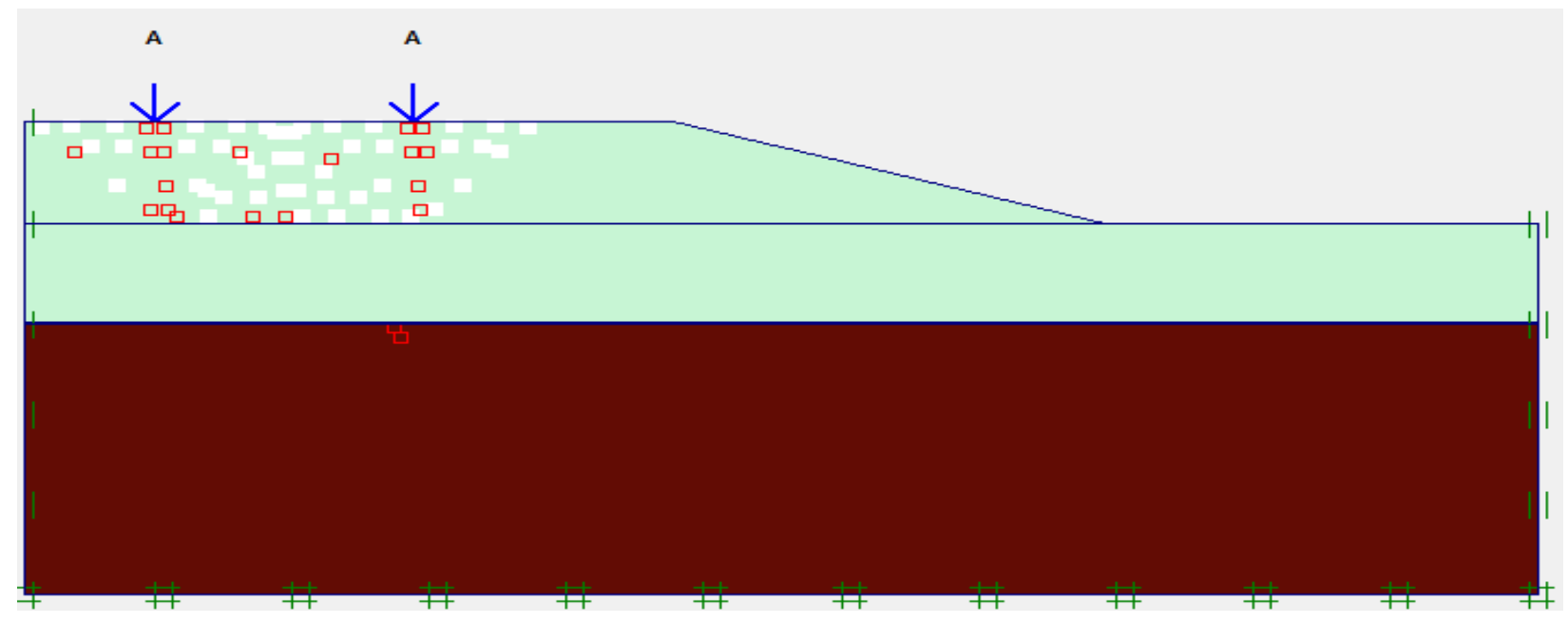

Figure 4. Plastic Points, Tensile stresses (tension cut-off)

\section{3-2- Plastic Points and Tension Cut-Off}

The modelling result as presented in Figure 5 shows that Mohr-Coulomb model was applied for all the soil layers. Figure 4. shows the plastic point concentrated most on the point of application of the load. It is observed that the plastic Coulomb points are concentrated in the upper base course of the point load. The tensile stresses (tension cut-off) are concentrated particularly on the base of the pavement. This tensile stress leads to the increment in length of deformation. The red open square indicates that the stress lies on the surface of the Coulomb surface envelop while the white open square indicate that the tension cut-off criterion was applied. 


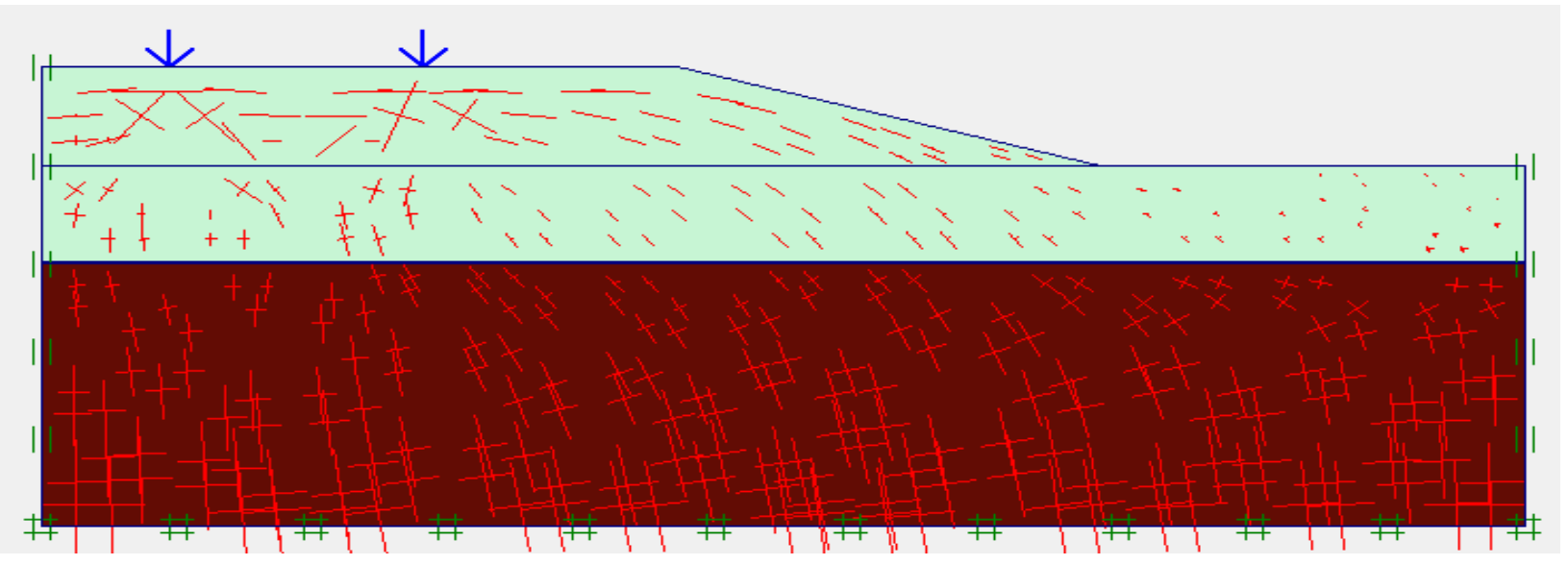

Figure 5. Effective Stress, Total effective stress acting on the entire pavement is $-85.16 \mathrm{KN} / \mathrm{m}$

\section{3-3-Effective Stress and Pore Water Pressure}

From Figure 5, it is shown that the stress operates at part of the pavement. At any point within the pavement, the magnitude of both total stress and pore water pressure are dependent on the ground water position. From the results, it shows that the total effective stress acting on the entire pavement is $-85.16 \mathrm{KN} / \mathrm{m}$ which shows that the force acting on the structure is compressional force. The total load acting on the base of the pavement is $100 \mathrm{KN} / \mathrm{m}$ and deformation on the pavement started at $85.16 \mathrm{KN} / \mathrm{m}$. It shows that the load to be applied on a base should not be up to $85.16 \mathrm{KN} / \mathrm{m}$.

\section{4-Conclusions}

- The Mohr-Coulomb model reveals that the deformations are concentrated exclusively on the base course, with the appearance of plastic tension cut-off points on base course

- The value of loads applied on the pavement is greater the bearing capacity of the soil. The load of $100 \mathrm{KN} / \mathrm{m}$ was applied and on iteration, it deformed at load $85.16 \mathrm{KN} / \mathrm{m}$.

- At any point within the pavement, the magnitude of both total stress and pore water pressure are dependent on the ground water position.

- The total effective stress acting on the entire pavement is $-85.16 \mathrm{KN} / \mathrm{m}$ which shows that the force acting on the structure is compressional force.

- The plastic point concentrated most on the point of application of the load.

- The plastic Coulomb points are concentrated in the upper base course of the point load.

- The load displacement acting on the base of the highway in study is $2.47 \times 10-{ }^{6} \mathrm{~m}$.

- Despite the fact that failure occurred, quarry dust stands to improve the existing soil as it showed that increase in quarry dust increases the dry density of the soil in study and decreases the moisture contents of the soil.

- Oguduasa-Oruruala (Isuikwuato) soil is completely loosed and requires thorough treatment before any pavement can be imposed to it.

- Since street lights are fixed objects, it is advisable to reinforce the position which they are to be fixed to avoid irrelevant settlement.

- It is also advisable to excavate the surface of the soil to about $0.5 \mathrm{~m}$ or a better soil should be used above the weak soil in order to make the newly added soil the base course

- Thorough consolidation and compaction should be applied to the different sections to avoid the soil settling at inappropriate time.

\section{5- Conflict of Interest}

The authors declare no conflict of interest.

\section{6- References}

[1] Akpokodje, Enuvie G., A. C. Tse, and Nnamdi Ekeocha. "Gully erosion geohazards in southeastern Nigeria and management implications." Scientia Africana 9, no. 1 (2010): 20-36. 
[2] Abdulfatai, I. A., I. A. Okunlola, W. G. Akande, L. O. Momoh, and K. O. Ibrahim. "Review of gully erosion in Nigeria: causes, impacts and possible solutions." Journal of Geosciences and Geomatics 2, no. 3 (2014): 125-129. doi:10.12691/jgg-2-3-8.

[3] E. E, Chikwelu, and Ogbuagu F. U. "Geotechnical Investigation of Soil Around Mbaukwu Gully Erosion Sites, South-Eastern Part of Nigeria.” IOSR Journal of Applied Geology and Geophysics 2, no. 4 (2014): 06-17. doi:10.9790/0990-0240617.

[4] Igbokwe, J. I., J. O. Akinyede, B. Dang, T. Alaga, M. N. Ono, V. C. Nnodu, and L. O. Anike. "Mapping and monitoring of the impact of gully erosion in Southeastern Nigeria with satellite remote sensing and Geographic Information System." The International Archives of the Photogrammetry, Remote Sensing and Spatial Information Sciences 37, no. Part B (2008): 865-71.

[5] Igwe, C.A. “Gully Erosion in Southeastern Nigeria: Role of Soil Properties and Environmental Factors.” Research on Soil Erosion (November 21, 2012). doi:10.5772/51020.

[6] Ezezika, Obidimma C., and Olorunfemi Adetona. "Resolving the gully erosion problem in Southeastern Nigeria: Innovation through public awareness and community-based approaches." Journal of Soil Science and Environmental Management 2, no. 10 (2011): 286-291.

[7] Osadebe, C. C., T. K. S. Abam, F. I. Obiora, and R. O. Sani. "Evaluating the Stability of Gully Walls in Agulu-Nanka-Oko gully erosion complex area of Anambra State, Nigeria, using empirical approach." Advancement in scientific and Engineering Research, vol2 (1) (2014): 35-43.

[8] Austad "Cement stabilization practice" Cherrybrooke, NSW Australia, Austab, (2012).

[9] Biggs, A. J. W., and K. M. Mahony. "Is soil science relevant to road infrastructure?." In 13th International Soil Conservation Organisation Conference, Conserving soil and water for society: Sharing solutions, Brisbane, ISCO. 2004.

[10] Awad, Islam, Noriyuki Yasufuku, and Hidetoshi Ochiai. "Erosion Rates of Soils Improved by Chemical Additives for Protection against Overland Flow." Memoirs of the Faculty of Engineering, Kyushu University 67, no. 4 (2007): 153-164.

[11] Boardman, D. I., S. Glendinning, C. D. F. Rogers, and C. C. Holt. "In Situ Monitoring of Lime-Stabilized Road Subgrade." Transportation Research Record: Journal of the Transportation Research Board 1757, no. 1 (January 2001): 3-13. doi:10.3141/1757-01.

[12] Chen, Renpeng, Vincent P. Drnevich, and Radha Krishna Daita. "Short-Term Electrical Conductivity and Strength Development of Lime Kiln Dust Modified Soils.” Journal of Geotechnical and Geoenvironmental Engineering 135, no. 4 (April 2009): 590594. doi:10.1061/(asce)1090-0241(2009)135:4(590).

[13] Hassan, M. M., M. Lojander, and O. Ravaska. "Characteristics of soft clay stabilized for construction purposes." In Advances in Transportation Geotechnics, pp. 665-670. CRC Press, 2008.

[14] Indraratna, Buddhima, Thevaragavan Muttuvel, and Hadi Khabbaz. "Investigating Erosional Behaviour of Chemically Stabilised Erodible Soils.” GeoCongress 2008 (March 7, 2008). doi:10.1061/40971(310)83.

[15] Indraratna, Buddhima, Thevaragavan Muttuvel, and Hadi Khabbaz. "Modelling the Erosion Rate of Chemically Stabilized Soil Incorporating Tensile Force - Deformation Characteristics." Canadian Geotechnical Journal 46, no. 1 (January 2009): 57-68. doi:10.1139/t08-103.

[16] Kitazume, M and Terashi, M. "The deep mixing method" Leiden, The Netherlands, CRC press/Balkema, (2013).

[17] Nalbantoglu, Zalihe, and Erdil Riza Tuncer. "Compressibility and Hydraulic Conductivity of a Chemically Treated Expansive Clay.” Canadian Geotechnical Journal 38, no. 1 (February 2001): 154-160. doi:10.1139/t00-076.

[18] Dhir, R. K., M. J. McCarthy, and P. A. J. Tittle. "Use of Conditioned PFA as a Fine Aggregate Component in Concrete." Materials and Structures 33, no. 1 (January 2000): 38-42. doi:10.1007/bf02481694.

[19] Sariosseiri, Farid, and Balasingam Muhunthan. "Effect of Cement Treatment on Geotechnical Properties of Some Washington State Soils.” Engineering Geology 104, no. 1-2 (February 2009): 119-125. doi:10.1016/j.enggeo.2008.09.003.

[20] Ouhadi, V.R., and A.R. Goodarzi. “Assessment of the Stability of a Dispersive Soil Treated by Alum.” Engineering Geology 85, no. 1-2 (May 2006): 91-101. doi:10.1016/j.enggeo.2005.09.042.

[21] EE, Arinze, and Okafor CC. "Finite Element Method of Stability Analysis and Stabilization of Gully Erosion Slopes - A Study of the Otampa Gu." Journal of Civil \& Environmental Engineering 07, no. 01 (2017). doi:10.4172/2165-784x.1000267.

[22] Arinze,E.E., Okonkwo,U.N and Ekeoma,E.C "Limit Equilibrium Method of Slope Stability Analysis and Stabilization of Gully Erosion Slope". Umudike Journal of Engineering Technology (UJET), (2017).

[23] Chetia, Malaya, Manash P. Baruah, and Asuri Sridharan. "Effect of Quarry Dust on Compaction Characteristics of Clay." Sustainable Civil Infrastructures (July 12, 2017): 78-100. doi:10.1007/978-3-319-61612-4_7.

[24] Chetia, Malaya, and Asuri Sridharan. "A Review on the Influence of Rock Quarry Dust on Geotechnical Properties of Soil." Geo-Chicago 2016 (August 8, 2016). doi:10.1061/9780784480151.019. 